\title{
INTEGRASI KONTEKS PENDIDIKAN AGAMA KRISTEN KEDALAM PELAKSANAAN PEMBELAJARAN
}

\author{
Lisna Novalia \\ Sekolah Tinggi Teologi Injili Arastamar (SETIA) Jakarta \\ Lisna.novalia29@gmail.com
}

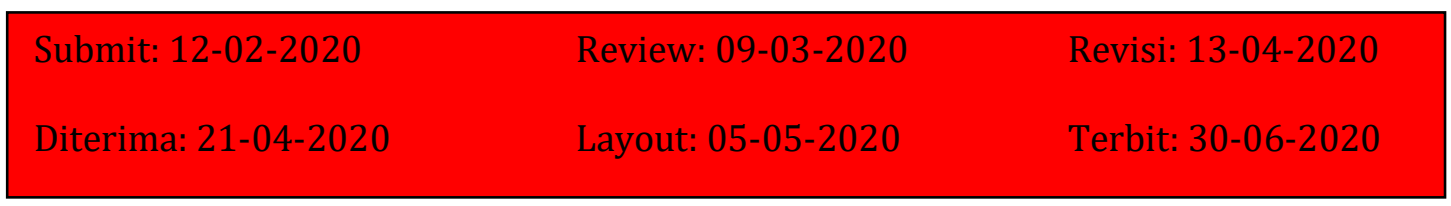

\begin{abstract}
Any education will always pay attention to the context. Likewise the Christian Religious Education cannot be separated from its context. The context which is always related to the principles and practices of Christian Religious Education is the family, church and school context. These three contexts have their own characteristics but they all lead to how Christian Religious Education can be carried out well and provide positive and good influence and results. This research emphasizes that Christian Religious Education practitioners always pay attention to the context in which Christian Religious Education is carried out. The method used in this research is library research with the intention of collecting various information or data from various sources, the data is processed and analyzed and conclusions are given. The findings of this study that the Christian Religious Education implemented cannot be separated from the context of the family, church and school.
\end{abstract}

Keywords: Family, Church, School, Teacher, Learning, Education, Religion, Christianity

\begin{abstract}
ABSTRAK
Pendidikan apapun akan selalu memperhatikan konteksnya. Demikian halnya dengan Pendidikan Agama Kristen tidak bisa dilepaskan dari konteksnya. Konteks yang selalu berhubungan dengan prinsip dan praktik Pendidikan Agama Kristen adalah konteks keluarga, gereja dan sekolah. Ketiga konteks ini memiliki ciri-ciri tersendiri namun semuanya mengarah pada bagaimana Pendidikan Agama Kristen dapat dilaksanaka dengan baik dan memberikan pengaruh dan hasil yang positif dan baik. Penelitian ini menekankan para pelaku Pendidikan Agama Kristen selalu memperhatikan konteks dimana Pendidikan Agama Kristen dilaksanakan. Metode yang digunakan penelitian ini adalah penelitian kepustakaan dengan maksud mengumpulkan berbagai informasi atau data dari berbagai sumber, data diolah dan dianalisis serta diberikan kesimpulan. Temuan dari penelitian ini bahwa Pendidikan Agama Kristen dilaksanakan tidak dapat dilepaskan dari konteks keluarga, gereja dan sekolah.
\end{abstract}

Kata Kunci: Keluarga, Gereja, Sekolah, Guru, Belajar, Pendidikan, Agama, Kristen. 


\section{PENDAHULUAN}

Dalam pembahasan ini, akan dianalisa dari konteks pendidikan secara umum dan konteks pendidikan secara khusus berkaitan dengan konteks Pendidikan Agama Kristen. Iris V.Cully mengatakan bahwa suatu proses belajar berlangsung dalam suatu konteks tertentu. ${ }^{1}$ Pendidikan baik pendidikan formal, informal, maupun non-formal selalu berlangsung dalam suatu konteks tertentu. Teori pendidikan dibentuk oleh konteks masyarakatnya. Teori pendidikan adalah suatu bingkai penuntun untuk secara sengaja menyelenggarakan pendidikan, memetakan konteks yang di dalamnya pendidikan itu dilaksanakan, menggambarkan tujuannya, menjelaskan dasar-dasarnya, dan mengajurkan praktik yang tepat. Oleh karena itu konteks memiliki andil dan ikut serta membentuk teori pendidikan. ${ }^{2}$

Keberhasilan suatu proses pembelajaran sangat tergantung pula pemahaman yang dimiliki tentang lingkungan dan konteks dimana pendidikan itu dilaksanakan. Berbagai kategori konteks tertentu dapat dikaitkan dengan pendidikan pada umumnya, yaitu konteks keluarga, konteks gereja, konteks sekolah, konteks pendidik, konteks peserta didik, kontek sarana dan prasarana, konteks filosofis, dan demografi dan geografis penduduk, konteks sosio antropologis religious, dan konteks lain-lainnya.

Pemahaman yang dibangun terhadap konteks pendidikan harus bersifat komprehensi dan integratrasi. Dengan memahami konteks pendidikan seperti yang dikemukakan di atas, maka diharapkan para pelaksana pendidikan khusus seperti pendidikan agama Kristen dapat menyusun perencanaan pembelajaran yang tepat. Karena tidak dapat disangkal bahwa keberhasilan suatu proses pendidikan dan suatu proses pembelajaran sangat dipengaruhi oleh konteks pendidikan itu sendiri.

\section{METODOLOGI PENELITIAN}

Metode yang digunakan adalah penelitian kepustakaan dengan teknik mengumpulkan berbagai informasi dari buku-buku dan internet, mengolah berbagai informasi tersebut dalam hasil dan pembahasan serta menarik kesimpulan dalam penelitian ini dengan judul Integrasi Konteks Pendidikan Agama Kristen ke dalam pelaksanaan Pembelajaran.

\section{HASIL DAN PEMBAHASAN}

Hasil dan pembahasan akan diarahkan pada ketiga konteks PAK. Sebagaimana diketahui bahwa tak seorangpun dapat menjadi Kristen yang baik dan menjadi berkat apabila ia hidup dalam keterasingan jauh dengan konteks dimana ia berada. Demikian pula menyangkut pendidikan Kristen. Pendidikan Kristen akan selalu dinamis berinteraksi dan terlihat hasilnya apabila bersentuhan dengan konteksnya.

Menurut Dirk Roy Kolibu, dengan memahami konteks pendidikan Kristen, maka diharapkan para pelaksana pendidikan agama (iman) Kristen dapat menyusun perencanaan pembelajaran yang tepat, khususnya menyangkut keluarga, gereja dan sekolah. Karena unsur keberhasilan suatu proses pendidikan ditentukan pula oleh

${ }^{1}$ Iris V. Cully, Dinamika Pendidikan Kristen (Jakarta:BPK. Gunung Mulia, 1993), 25

${ }^{2}$ Hope S. Antone, Pendidikan Kristiani Kontekstual (Jakarta:BPK.Gunung Mulia, 2010), 7 
pemahaman yang dimiliki tentang konteks pendidikan itu sendiri. ${ }^{3}$ Berdasarkan pertimbangan di atas, akan dibahas konteks pendidikan Kristen dari sudut pandang keluarga, gereja dan sekolah.

\section{Konteks Keluarga}

Pembahasan konteks keluarga akan difokuskan pada beberapa indikator utama pengertian keluarga Kristen, pentingnya keluarga Kristen, prinsip utama dalam keluarga Kristen, peran dalam keluarga Kristen, dan hirarki keluarga Kristen.

\section{a. Pengertian Keluarga Kristen}

Menurut KBBI, keluarga adalah: (1) Ibu dan bapak beserta anak-anaknya, seisi rumah. (2) Orang seisi rumah yang menjadi tanggungan, (3) Kaum, sanak saudara, dan kaum keluarga, (4) satuan kekerabatan yang sangat mendasar dalam masyarakat. ${ }^{4}$

Menurut suatu sumber, pengertian keluarga menurut UU. No. 10 Tahun 1992 adalah unit terkecil dari masyarakat yang terdiri dari suami-istri atau suami-istri dan anaknya atau ayah dan anaknya atau ibu dan anaknya. Dari Departemen Kesehatan RI keluarga adalah unit terkecil dari masyarakat yang terdiri dari kepala keluarga dan beberapa orang yang berkumpul dan tinggal di suatu tempat di bawah satu atap dalam keadaan saling ketergantungan. Dalam Undang-Undang Nomor 52 Tahun 2009 Bab 1 Pasal 1 ayat 6 tentang Perkembangan Kependudukan dan Pembangunan Keluarga adalah unit terkecil dalam masyarakat yang terdiri atas suami istri, atau suami, istri dan anaknya, atau ayah dengan anak (duda) atau ibu dengan anaknya (janda). Pandangan Badan Kependudukan dan Keluarga Berencana Nasional (BKKBN) adalah unit terkecil dalam masyarakat yang terdiri dari suami isteri atau suami isteri dan anak-anaknya atau ibu dan anak-anaknya. Menurut Spradley dan Allender, keluarga adalah satu atau lebih yang tinggal bersama, sehingga mempunyai ikatan emosional dan mengembangkan dalam interelasi sosial, peran dan tugas. Sedangkan keluarga menurut Salvicion dan Celis adalah kumpulan dua orang atau lebih yang hidup bersama dengan keterikatan aturan dan emosional dan setiap individu memiliki peran masing-masing. ${ }^{5}$

Keluarga atau rumah tangga Kristen merupakan unit terkecil dalam suatu komunitas masyarakat yang secara hukum dan agama telah beroleh hak dan kewajibannya untuk eksis dan bertanggung jawab dalam masyarakat. Menurut Helmut, keluarga Kristen adalah persekutuan hidup antara ayah, ibu, dan anak-anak yang telah percaya dan menerima Yesus Kristus sebagai Tuhan dan Juru selamat secara pribadi serta meneladani hidup dan ajaran-ajaran-Nya dalam kehidupan sehari-hari. Pengertian ini dibangun dari pengertian Kristen itu sendiri. Kristen artinya menjadi pengikut Kristus, yang meneladani hidup dan ajaran-ajaran Kristus. ${ }^{6}$

${ }^{3}$ Dirk Roy Kolibu, Teologi Pendidikan Agama Kristen (Jakarta: Pascasarjana UKI, 2020), 69

${ }^{4}$ Departemen Pendidikan dan Kebudayaan, Kamus Besar Bahasa Indonesia (Jakarta: PT. Gramedia Pustaka Utama, 2014), 659.

${ }^{5}$ Dalam https://www.seputarpengetahuan.co.id/2017/08/15-pengertian-keluarga-menurut-paraahli.html, diunduh hari Rabu tanggal 22 April 2020 pukul 17:00 WIB

${ }^{6}$ Helmut, dalam http://www.charismata.id/2017/05/pengertian-keluarga-kristen.html, diunduh hari Rabu tanggal 22 April 2020 pukul 17:00 WIB 
Keluarga Kristen adalah keluarga atau rumah tangga yang terbentuk dari pasangan laki dan perempuan dalam bingkai sosial, hukum, adat istiadat, dan agama diberkati dalam pernikahan kudus yang telah percaya dan mengakui Yesus Kristus sebagai Tuhan dan Juruselamatnya, mempercayai Alkitab sebagai firman Tuhan yang menjadi penuntun kehidupan keluarga, menerima dan mengikuti tuntuntan Roh Kudus dalam mengarungi biduk keluarganya selama di dunia. Dalam proses pembentukan keluarganya telah direstui dan diterima keluarga dari kedua belah pihak, dapat memperoleh anak sesuai dengan kehendak Tuhan dari hubungan suami istri, dari mengadopsi anak sesuai dengan kemauan diri sendiri dan hukum dan bersedia melaksanakan tanggung jawab dalam keluarga, masyarakat, gereja, dan bangsa.

\section{b. Pentingnya keluarga Kristen}

Menurut Homrighausen dan Enklaar, keluarga Kristen adalah pemberian Tuhan yang tak ternilai harganya. Keluarga Kristenlah yang memegang peranan terpenting dalam PAK, bahkan lebih penting dari segala jalan yang dipakai gereja untuk pendidikan itu. Baik anak dan orangtua memperoleh berkat rohani besar di dalam keluarga yang dipimpin oleh Roh Kudus. Apabila keluarga ini disucikan dan dikuasai Yesus Kristus sendiri, niscaya keluarga itu menjadi taat dan kuat dalam tangan Tuhan untuk memperkembangkan dan mematangkan pribadi-pribadi Kristen yang luhur. ${ }^{7}$ Menurutnya keluarga Kristen penting dengan alasan sebagai wadah pembentukan kepercayaan Kristen yaitu kepercayaan kepada Tuhan. Alkitab dalam Perjanjian Lama dan Perjanjian Baru, menekankan bahwa dari keluargalah permulaan anak mempercayai dan mengenal Allah. Keluarga juga merupakan benteng yang kuat dalam menangkal atau melawan musuh-musuh keluarga Kristen yaitu penolakan tidak berkeluarga, penolakan pendidikan anak, ketidaksetiaan suami dan istri, ketidakpercayaaan, perceraian, pemberontakan, ketidakpedulian gereja terhadap keluarga. Selain itu, keluarga penting karena di dalam keluarga Kristenlah pertama dilakukan pengajaran dan pembinaan iman.

Menurut G. Reimer, keluarga menduduki posisi penting dalam Alkitab oleh karena Allah ternyata tidak mengadakan perjanjian dengan individu, melainkan dengan satu umat yang terdiri dari orangtua dengan anak-anaknya. ${ }^{8}$ Sedangkan menurut Ted Ward, keluarga adalah penting, terutama bagi orang Kristen. Hubungan khusus Allah dengan umat-Nya dimaksudkan untuk dilaksanakan melalui keluarga. Keluarga adalah suatu nilai dan pembentukan nilai kehidupan. Allah telah menciptakan manusia dengan kebutuhan-kebutuhan tertentu yang memerlukan suatu keluarga. Keluarga manusia berbeda dengan jenis binatang yang beranak. Keluarga manusia menyediakan rasa aman, naungan, perlindungan, pemeliharaan, rasa kasih sayang, rasa menjadi anggota kelompok, suatu lingkungan belajar, dan sebuah landasan yang aman. Dari landasan inilah anak yang dewasa memulai sebuah keluarga baru. ${ }^{9}$

Stephen Tong menjelaskan bahwa Pendidikan Agama Kristen dalam keluarga merupakan hal fundamental karena pendidikan ini merupakan dasar dari seluruh pendidikan-pendidikan lainnya. Maksudnya, keluarga sebagai unit terkecil dan dasar yang membentuk masyarakat dan dasar suatu bangsa yang kuat dan gereja yang sejati. ${ }^{10}$

7E.G. Homrighausen dan I.H. Enklaar, Pendidikan Agama Kristen (Jakarta: BPK. Gunung Mulia, 2008), 128-129.

${ }^{8}$ G. Riemer, Ajarlah Mereka Melakukan (Jakarta: YKBK/OMF, 2006), 12

9Ted Ward, Nilai Hidup dimulai dari Keluarga (Malang: Gandum Mas, 1976), 10

${ }^{10}$ Stephen Tong, Keluarga Bahagia (Surabaya: Momentum, 2012), 99 
Selain itu menurut Daniel Nuhamara, keluarga merupakan wadah paling potensial untuk menanamkan iman yang kokoh sebagai pembentukan kepribadian dan pembentukan karekter. ${ }^{11}$

\section{c. Prinsip utama keluarga Kristen}

Musa mengungkapkan bahwa munculnya keluarga Kristen karena kehendak Allah. Dalam Ulangan 1:27-28 dan Ulangan 2:20-24, Allah merencanakan dan merealisasikan institusi keluarga dalam dunia untuk menggenapi dan menikmati janji Allah. Yesus Kristus sebagai tiang dan kepala keluarga dan gereja menganggap penting institusi keluarga. Proses inkarnasi-Nya di dunia, melalui institusi keluarga Yahudi dari keturunan Yusuf dan Maria. Oleh pekerjaan Roh Kudus, Ia masuk dalam rahim dan lahir dari rahim Maria, Ia masuk dan lahir dari rumah tangga Yusuf dan Maria sebagai tanda bahwa keluarganya sebagai legetimasi kehadiran-Nya di dunia. Yesus adalah salah satu keluarga inti dari Yusuf dan Maria di samping saudara-saudari lainnya.

Stephen Tong menegaskan bahwa prinsip pembentukan keluarga Kristen adalah pada kehendak Allah yang kekal. Dimana menurutnya, terdapat empat alasan prinsip ini ditekankan dalam keluarga Kristen yaitu Allah menjadi dasar kedudukan keluarga Kristen, Allah menjadi tujuan keluarga, dan Allah menjadi dasar kesamarataan priawanita, dan Allah menjadi pola-urutan (ordo) pria-wanita. ${ }^{12}$

\section{d. Peran Keluarga Kristen}

Kenneth Chafin dalam bukunya Is There a Family in the House? memberi gambaran tentang maksud keluarga dalam lima identifikasi perannya, yaitu: (1) Keluarga merupakan tempat untuk bertumbuh, menyangkut tubuh, akal budi, hubungan sosial, kasih dan rohani. Manusia diciptakan menurut gambar Allah sehingga mempunyai potensi untuk bertumbuh. Keluarga merupakan tempat memberi energi, perhatian, komitmen, kasih dan lingkungan yang kondusif untuk bertumbuh dalam segala hal ke arah Yesus Kristus. (2) Keluarga merupakan pusat pengembangan semua aktivitas. Dalam keluarga setiap orang bebas mengembangkan setiap karunianya masing-masing. Di dalam keluarga landasan kehidupan anak dibangun dan dikembangkan. (3) Keluarga merupakan tempat yang aman untuk berteduh saat ada badai kehidupan. Barangkali orang lain sering tidak memahami kesulitan hidup yang kita rasakan tetapi di dalam keluarga kita mendapat perhatian dan perlindungan. (4) Keluarga merupakan tempat untuk mentransfer nilai-nilai, laboratorium hidup bagi setiap anggota keluarga dan saling belajar hal yang baik. (5) Keluarga merupakan tempat munculnya permasalahan dan penyelesaiannya. Tidak ada keluarga yang tidak menghadapi permasalahan hidup. Seringkali permasalahan muncul secara tidak terduga. Misalnya, hubungan suami istri, masalah yang dihadapi anak belasan tahun, dan masalah ekonomi. Namun, keluarga yang membiarkan Kristus memerintah sebagai Tuhan atas hidup mereka pasti dapat menyelesaikan semua permasalahan.

Wuwungan menjelaskan bahwa Tuhan menghendaki orangtua mengajarkan kepada anak-anaknya, ajaran itu diteruskan pada generasi berikutnya, sehingga

11Daniel Nuhamara, Pembimbing Pendidikan Agama Kristen (Bandung: Infomedia, 2007), 50

12Tong, Keluarga Bahagia, 11-14 
pendidikan secara terus menerus harus dilaksanakan. ${ }^{13}$ Ayah dan ibu berperan aktif dalam pertumbuhan rohani anak-anaknya, tanggung jawab mereka yang utama dan paling mendasar adalah mengajar Firman Allah untuk mengutamakan Allah dalam hidup mereka. Orangtua mempunyai pengaruh besar dalam pembentukan identitas diri yaitu murid Kristus. ${ }^{14}$ Anne Neo Feld Rupp mengulas peran keluarga Kristen yaitu haruslah: (1) Membangun persekutuan keluarga, (2) Melayani kehidupan anak-anak dalam keluarga, (3) Mendidik anak dalam didikan Kristen melalui nasihat dan teguran Alkitabiah, (4) Mengkomunikasikan iman lewat keteladanan hidup orangtua, seperti membangun ikatan kasih sesama orangtua keluarga, mengembangkan sukacita dan komitmen dalam keluarga, saling menghormati dan menunjukkan kepedulian kepada sesama. 15

Sitompul menjelaskan bahwa keluarga harus mengupayakan pertumbuhan rohani bukan saja menyangkut iman dan pengetahuan tentang Allah, tetapi menyangkut kualitas anak-anak dalam menghadapi tantangan zaman, mampu berpikir kritis sehingga menolak paham atau ajaran yang bertentangan dengan iman Kristen sebagai bentuk kedewasaan rohani. ${ }^{16}$

Dirk Roy Kolibu mengatakan bahwa pelaksanaan PAK dalam keluarga dimulai dari mengajarkan iman pada Kristus dan pengetahuan yang benar tentang Allah, karena kita hidup di tengah-tengah situasi relatif dan subyektif sehingga iman Kristen harus terimplementasi secara nyata. Anak-anak dalam keluarga dididik untuk berpikir kritis sehingga mampu mempertahankan iman di tengah-tengah arus globalisasi. Anak-anak dalam keluarga harus juga perlu diajarkan bagaimana mengintegrasikan iman dan keseimbangan moral dan etika Kristen, antara teori dan praktik, sebab iman tanpa perbuatan adalah mati ( Yak. 2:26). Selain itu dalam keluarga harus ada ikatan kasih yan kuat, saling menopang, saling menolong dan orangtua adalah figur teladan moral, iman, dan kerja.

Oleh karena itu peran orantua jangan diabaikan dan terputus-putus, pendidikan dalam keluarga terutama pendidikan moral, rohani dan etos kerja harus tetap dijalankan. Pendidikan keluarga yang baik keluar dari narasi dan teladan hidup yang nyata dan berkelanjutan sepanjang hayat hidup keluarga Kristen itu sendiri.

\section{Konteks Gereja}

Pembahasan konteks gereja akan difokuskan pada beberapa indikator utama yaitu pengertian gereja, hikmat gereja, dan fungsi gereja.

\section{a. Pengertian Gereja}

Menurut KBBI, gereja adalah: (1) tempat ibadah umat Kristen, gedung (rumah) tempat berdoa dan melakukan upacara agama Kristen, (2) Badan (organisasi) umat Kristen yang sama kepercayaan, ajaran, dan tata cara ibadahnya. ${ }^{17}$

${ }^{13}$ O.E.CH. Wuwungan, Pemahaman Alkitab dan Warga Gereja (Jakarta: Pustaka Sinar Harapan, 1997), 311

${ }^{14}$ Daniel Nuhamara, Pendidikan Agama Kristen di Perguruan Tinggi (Bandung:Bina Media Informasi, 2007), 51

${ }^{15}$ Anne Neo Feld Rupp, Tumbuh Kembang Bersama Anak (Jakarta:BPK. Gunung Mulia, 2009), 7-9

${ }^{16}$ A.A. Sitompul, Mencerdaskan Anak Bangsa Menuju Millenium Baru (Jakarta: Kebangkitan Hidup Baru, 1999), 60

${ }^{17}$ Departemen Pendidikan dan Kebudayaan, Kamus Besar Bahasa Indonesia, 445 
Randolph Crump Miller menyatakan bahwa gereja adalah miliki Kristus, yaitu umat Kristiani yang tampak pada masa kini bersama-sama dengan umat Kristiani yang telah wafat pada masa lampau. Gereja adalah umat yang telah ditebus dan bersatu dalam persekutuan Roh Kudus. Eli Tanya memaparkan banyak kiasan hidup yang menggambarkan arti dan makna gereja yaitu gereja sebagai tubuh Kristus (1 Kor. 12:4; Rm.12:4), Gereja sebagai umat Allah (Yer. 11:40; 2 Pet. 2:9), Gereja sebagai persekutuan Roh Kudus (Kis.2), Roh Kudus menuntun pada kekudusan hidup (1 Pet. 1:15), dan pelaksanaan misi Kristus (1 Kor. 10;16), Gereja adalah ekklesia "umat yang dipanggil keluar untuk menjadi umat Kristus ( Kis. 9:21; Gal. 4:2; 1:3), Gereja sebagai Perjanjian Baru (Mrk. 14:24; Yer. 31:31-34), Gereja sebagai jalan, gaya hidup, dan etika hidup (Kis.9:2). ${ }^{18}$ Beranjak dari pengertian ini, gereja dalam Perjanjian Baru untuk umat Kristiani atau organisme gereja dimetaforakan sebagai: (1) Gereja sebagai kawanan domba Allah (Yoh. 10) dimana Tuhan adalah gembalanya (Yeh. 34). (2) Gereja sebagai pokok anggur (Mrk. 12;1-12, orang Israel sebagai pokok anggur (Yes. 5) dan anggotaanggota gereja adalah carang-carangnya (Yoh.15). (3) Gereja sebagai bangunan, dimana anggota-anggotanya sebagai batu-batunya (1 Pet.2:5; Ef. 2:20; 1 Kor.3:9). (4) Gereja sebagai mempelai perempuan dan Yesuslah sebagai mempelai laki-lakinya ( Mrk. 2;9; Why.19:17). ${ }^{19}$

Dari penjelasan di atas, nampak bagi kita bahwa gereja mengacu pada dua hal yaitu: Pertama, Gereja sebagai pribadi, oknum, dan organisme yang terdiri tubuh, jiwa, dan roh atau terdiri dari tubuh jasmani dan tubuh rohani. Gereja ini yang menyangkut pada setiap orang percaya dari zaman ke zaman, dari waktu ke waktu dulu, sekarang dan yang akan datang. Kedua, Gereja mengacu pada komunitas dan kelompok yang berkumpul dalam suatu lingkungan masyarakat yang disebut sebagai komunitas Kristen, orang percaya, atau penganut kepercayaan kepada Kristus (Kristiani) yang berkumpul dalam suatu perserikatan, persekutuan, dan lembaga gereja. Pengertian kedua ini menyangkut organisasi dan institusi keagamaan dan pendidikan.

Untuk proses belajar Kristen, gereja adalah konteksnya. ${ }^{20}$ Proses pembelajaran Pendidikan Agama Kristen dalam konteks gereja adalah tentunya mereferensi kedua maksud di atas sehubungan dengan gereja. Pendidikan Agama Kristen harus dijalankan secara pribadi dan juga secara organisasi dan institusi baik dalam lembaga keagamaan (organisasi-organisasi gereja) dan institusi pendidikan dibawah pemerintah dan yayasan-yayasan sosial kemasyarakatan.

\section{b. Hikmat Gereja}

Takut akan Tuhan adalah permulaan pengetahuan dan hikmat (Ams. 1:7). Pusat hikmat Gereja adalah Allah Bapa, Allah Anak (Yesus Kristus) dan Allah Roh Kudus. Pendirian Gereja di dunia diprakarsai sendiri oleh Allah melalui pemanggilan umat Israel melalui benih Abraham (Kej. 12) dan deklarasi Kristus atas pendirian Gereja di bumi (Mat. 16:13-20). Hikmat Gereja menjadi dasar dalam menangkal ajaran-ajaran yang tidak sehat dan menyesatkan (1 Tim.6:3-4a; 2 Tim.4:3). Hikmat Gereja dalam Kristus dan Roh Kudus akan menuntun umat-Nya membina diri dan keturunan serta generasi demi generasi. Gereja akan memiliki vitalitas hidup apabila para orangtua

18Ely Tanya, Gereja dan Pendidikan Agama Kristen (Cipanas: STTC, 2006), 9-11

19Tanya, Gereja dan Pendidikan Agama Kristen, 12

${ }^{20}$ Cully, Dinamika Pendidikan Kristen, 25 
bertanggung jawab dalam hal ihwal pendidikan dan pengajaran anak-anak mereka dan bagi anak-anak wajib taat belajar firman Tuhan (Yer. 31:29-30). ${ }^{21}$

Yesus Kristus adalah kepala Gereja. Gereja tidak dapat hadir dan berfungsi tanpa Kristus. Kepala dan tubuh secara kodrat satu, demikian juga Kristus sebagai kepala dan tubuh-Nya yaitu orang-orang percaya kepada-Nya. Kepala tubuh adalah Kristus.

\section{c. Fungsi dan Tujuan Gereja}

Fungsi gereja terkait dengan kerygma (pemberitaan) dan didache. Kerygma menunjuk kepada pesan utama yaitu berita tentang Injil Kristus dimana lewat perbuatan-perbuatan ajaib Tuhan melawat dan menebus umat-Nya. Didache selalu terkait dengan kerygma berita Injil Kristus. Pengajaran akan menuntun seseorang semakin dewasa dalam pengetahuan, sikap dan keterampilan hidup sebagai seorang kristiani.

Ely Tanya menyusun kerangka pikir tentang fungsi gereja berdasarkan pemikiran dari Randolph Crum Miller sebagai berikut: Pertama, fungsi ibadah yang menunjukkan cara berhubungan dengan Allah dengan benar. Dengan permohonan, ucapan syukur, memuliakan Tuhan, mengaku dosa dan memuji Allah adalah cara yang benar dari orangorang percaya berkomunikasi dengan Allah dalam ibadah. Kedua, Persekutuan. Gereja adalah persekutuan orang-orang yang kudus dan beriman. Setiap umat yang masuk dalam gereja adalah umat yang kudus dari Roh Kudus. Ketiga, Pengajaran. Gereja harus mengajar dan berkhotbah tentang pribadi,sifat, karya dan anugerah Tuhan. Gereja memiliki tugas mewariskan iman dan pengajaran kepada generasi berikutnya. Keempat, misi. Gereja harus menyebarkan Injil Kristus ke seluruh jagat raya dan generasi demi generasi. Misi adalah perintah langsung dari Kepala Gereja (Mat. 28:19-20). Kelima, pelayanan pastoral. Gereja terpanggil pada pendewasaan, pemeliharaan, dan penguatan orang-orang percaya. Gereja harus melaksanakan bakti sosial di sekitarnya. Keenam, gerakan oikumene. Gereja melampaui batas-batas nasional, ras, budaya, dan bangsa. Gereja harus ke luar memberitakan Injil Kristus melalui "Tri Tugas Gereja” yaitu persekutuan (koinonia), kesaksian (marturia), dan pelayanan (diakonia). ${ }^{22}$

Berangkat dari pemikiran fungsi gereja, maka gereja adalah konteks utama bagi pendidikan transformatif dan pertumbuhan iman dan juga bagi perubahan komunitas dan sosial ke arah etika kehidupan. Pendidikan jemaat merupakan panggilan pelayanan yang akan dirasakan, diarahkan, dan dievaluasi dalam terang Injil Kerajaan Allah. Pendidikan gereja melibatkan kehidupan jemaat, yaitu ibadah, komunitas, dan misi.

Saymor mengatakan bahwa pendidikan Kristiani menjadikan "ibadah" sebagai pengakuan dan perayaan atas pemerintahan Allah, pendidikan Kristiani melengkapi komunitas untuk hidup sebagai keluarga Allah dan masyarakat, dan pendidika Kristiani memberdayakan misi, yakni memberitakan Injil dan memajukan Kerajaan Allah melalui kehadiran, tindakan, dan perkataan orang-orang percaya. ${ }^{23}$

Dirk Roy Kolibu menjelaskan bahwa untuk memahami konteks pendidikan agama Kristen dalam gereja, maka hal yang penting dipahami adalah apa tujuan gereja. Kristus yang mendirikan gereja di dunia tentunya memiliki tujuan. Tujuan gereja adalah

21Riemer, Ajarlah Mereka Melakukan, 18

22Tanya, Gereja dan Pendidikan Agama Kristen, 12-16

${ }^{23}$ Daniel S. Schipani, "Pendidikan Transformasi Sosial" dalam Memetakan Pendidikan Kristen: Pendekatan-pendekatan menuju Pembelajaran Jemaat. Penyunting Jack L. Saymour (Jakarta: BPK. Gunung Mulia, 2016), 41 
berkenaan dengan deklarasi Kristus tentang berdirinya gereja untuk mewartakan Injil Kristus. Gereja sebagai penerima mandata Agung Kristus mempunyai cita-cita luhur untuk menjadikan semua bangsa murid Tuhan Yesus Kristus (Mat. 28:19-20). Gereja dapat melakukan tugasnya hanya jika disertai kuasa dan kekuatan Tuhan. ${ }^{24}$ Seluruh aktifitas gereja harus menjawab dan menerangkan karya penebusan Kristus bagi umat manusia.

\section{Konteks Sekolah}

Pembahasan konteks sekolah akan difokuskan pada beberapa indikator utama pengertian sekolah, sekolah sebagai tempat proses pembelajaran PAK, kurikulum PAK, dan pelaksana PAK konteks sekolah.

a. Pengertian Sekolah

Pendidikan Agama Kristen bukan saja diberikan di gereja di dalam dalam lingkunganya sendiri, tetapi juga di luar lingkungannya itu, yakni di dalam sekolahsekolah umum. Sekolah-sekolah negeri bersikap netral terhadap agama-agama yang dianut oleh rakyat, karena diselenggarakan oleh negara yang memang juga tidak memihak sesuatu agama yang tertentu. ${ }^{25}$ Namun penting diketahui bahwa sekolahsekolah tidak hanya didirikan oleh pemerintah, pihak swasta, tetapi juga banyak sekolah didirikan oleh yayasan Kristen yang memang menginginkan sekolah-sekolah tersebut mencirikan nuansa pendidikan Kristen.

Menurut KBBI, sekolah adalah: (1) Bangunan atau lembaga untuk belajar dan mengajar serta tempat menerima dan memberi pelajaran (menurut tingkatannya), (2) Waktu atau pertemuan ketika murid diberi pelajaran. (3) Usaha menuntut kepandaian (ilmu pengetahuan) melalui pelajaran dan pengajaran. ${ }^{26}$ Richard Edelin mengatakan bahwa sekolah adalah institusi sosial tempat para murid belajar tentang dunia dan tempat mereka serta tugas panggilan di dalamnya. ${ }^{27}$

Dari pengertian di atas dapat dipahami bahwa sekolah berupa tempat yang dapat menyelengarakan pendidikan dan pengajaran dengan baik dan aman. Sekolah dengan seluruh keberadaan dan kegiatannya harus sesuai dengan ketentuan peraturan dan perundang-undangan yang berlaku. Sekolah sebagai satu-satunya institusi yang dapat menyenggarakan satuan-satuan pendidikan dan jenjang pendidikan dari pendidikan dasar sampai perguruan tinggi yang menghasilkan output dan outcome yang diharapkan keluarga, gereja, masyarakat dan pemerintah.

Sekolah harus mampu memberikan akses bagi yang membutuhkan dan rasa aman bagi yang menjalankan segenap program pendidikan dan pengajaran. Sekolah juga harus mampu mendidik dan meluluskan para lulusan yang siap bekerja, bersaing, dan memenuhi tuntutan industri pekerjaan. Amat terlebih dalam kontek pendidikan sekarang, kemerosotan moral dan rohani dianggap sebagai kegagalan sekolah dalam menghasilkan lulusan-lulusan yang memiliki karakter dan integritas hidup.

\footnotetext{
${ }^{24}$ Jonathan Parapak, Pembelajar dan Pelayan: Di sekitar iman, teknologi, pendidikan dan pelayanan gerejawi (Jakarta: Institut Dharma Mahardika, 2002), 44

${ }^{25}$ EG. Homrighausen dan I.H. Enklaar, Pendidikan Agama Kristen (Jakarta: BPK. Gunung Mulia, 2008), 148

26Departemen Pendidikan dan Kebudayaan, Kamus Besar Bahasa Indonesia, 1244

${ }^{27}$ Richard J. Edelin, Hakikat Pendidikan Kristen (Jakarta: BPK. Gunung Mulia, 2015), 60
} 
b. Sekolah sebagai tempat proses pembelajaran PAK

Banyak negara tidak menginjinkan Pendidikan Agama (khususnya PAK) dilaksanakan di sekolah. Indonesia sebagai negara domokratis masih menjunjung tinggi pelaksanaan pembelajaran agama di sekolah-sekolah. Pemerintah memberikan kesempatan seluas-luasnya bagi pemeluk agama di sekolah untuk mempelajari ajaran agama atau kepercayaannya. Pemerintah berpihak tidak hanya menginjikan, menyusun kurikulum, menyediakan tenaga pendidik yang seagama dengan peserta didik dan rumpun mata pelajaran/kuliah yang diajarkan, dan juga menyediakan dana yang cukup besar bagi operasional sekolah dan peningkatan sumber daya manusianya.

Kesempatan baik ini wajib dimanfaatkan dengan menanamkan benih panggilan mengajar bagi para guru-guru baik negeri dan swasta agar mereka mengajar sungguhsungguh dan tidak hanya sekedar melaksanakan tugas karena digaji melainkan karena terpanggil dan diizinkan Tuhan mengajar PAK di sekolah tersebut.

Menurut Homrighausen dan Enklaar, khususnya PAK di sekolah-sekolah negeri sangat menguntungkan dilihat dari indikator: Pertama, Gereja dapat memanfaatkan kesempatan memberitakan Yesus Kristus lewat pelajaran agama. Kedua, anak-anak dapat mempelajari PAK di sekolah sama seperti mempelajari mata pelajarannya lainnya. Dengan jalan ini, terbuka kesempatan lewat jalur hukum para guru melaksanakan pemberitaan Injil melalui mengajar sebaliknya juga peserta didik mendapatkan kesempatan berharga untuk mendengarkan Firman Tuhan dan menerima Yesus sebagai Tuhan dan Juruselamatnya. Ketiga, gereja tertolong dari sisi keringanan biaya. Karena keseluruhan biaya sudah ditanggung oleh pemerintah. ${ }^{28}$ Sekolah-sekolah Kristen di Indonesia tentu merupakan tugas dan tanggung jawab yang indah tetapi berat juga bagi gereja. Karena tidak hanya diperhadapkan pada kesempatan yang berharga tetapi juga diperhadapkan pada berbagai pergumulan seperti sarana prasarana, tenaga SDM, tata kelola dan manajemen, dan faktor lingkungan serta peraturan dan kebijakan di setiap daerah yang berbeda-beda.

Pada umumnya, lembaga pendidikan Kristen hanya lebih fokus pada praksis pendidikan yang menekankan prestasi akademik semata. Daniel Stefanus menganalisa kecendrungan ini akan sangat berdampak negatif pada kegagalan PAK di sekolahsekolah, yakni: (1) Pendidikan agama kita selama ini ditengarai masih berpusat pada hal-hal yang bersifat simbolik, ritualistik, dan legal formalistic. (2) Pendidikan agama cenderung bertumpu pada penggarapan ranah kognitif dan ranah afektif. (3) Pendidikan agama di sekolah tidak berhasil meningkatkan etika dan moralitas, serta kerohanian peserta didik. (4) Pendidikan agama dipahami sebagai ilmu bukan laku. (5) Soal pendidikan, orantua menyerahkan sepenuhnya kepada pihak sekolah. (6) Pendidikan agama cenderung bersifat eksklusif. ${ }^{29}$

\section{c. Kurikulum PAK di sekolah}

Kurikulum PAK di sekolah hendaknya didasarkan pada visi dan misi Kristen yang termuat dalam Alkitab. Alkitab dengan jelas menyebutkan bahwa tanpa visi dan misi suatu bangsa akan hancur. Dalam ladang pelayanan pendidika Kristen, sekolah-sekolah Kristen harus dikelolah dengan visi dan misi manajemen modern berdasarkan prinsipprinp alkitabiah. Kalau pun dipandang sebagai "industry" dapatlah dikatakan dengan

${ }^{28}$ Hamrighausen dan Enklaar, Pendidikan Agama Kristen, 151

${ }^{29}$ Daniel Stephanus, Pendidikan Agama Kristen Kemajemukan (Bandung: Bina Media Indonesia, 2009), 91 
noble industry, suatu pelayanan yang mengandung nilai-nilai yang memuliakan Tuhan, dengan prinsip alkitabiah. ${ }^{30}$

Sekolah Kristen berbeda dengan sekolah sekuler. Sekolah Kristen dan pendidik yang ada di dalamnya bukanlah berasal dari dunia, melainkan Tuhanlah yang memilih penatalayanan pendidikan Kristen di tengah dunia (Yoh. 15:19; 17:18). Keberadaan sekolah Kristen berasal dari kasih karunia Tuhan yang missioner. Oelh karena itu, sekolah Kristen bertujuan mempersiapkan murid-muridnya untuk kehidupan masa mendatang dan kekalan. Sekolah Kristen mempersiapkan murid-muridnya dibentuk untuk memahami realitas ciptaan Tuhan dalam persepktif Kristen (Christian mind). ${ }^{31}$

Pendidikan Kristen adalah pendidikan yang lahir karena suatu misi. Sekolah Kristen adalah sekolah yang lahir karena panggilan Kristus. Seberapa kuat misi kita dalam tugas pendidikan akan tampak dari kualitas kita memberikan pelayanan sekolah Kristen. Tugas sekolah Kristen memberikan pelayanan pendidikan, pembinaan, pemeliharaan, dan pengajaran dalam Christian Formation dan Christian nurturing. Fokus pendidikan Kristen haruslah mengajarkan kebenaran firman Tuhan yang menyatakan Allah Bapa sebagai pencipta manusia dan alam serta segalah isinya, menyatakan Tuhan Yesus Kristus sebagai Anak Allah yang datang ke dunia menebus dosa manusia, memulihkan gambar dan rupa Allah yang sudah rusak akibat doa, serta mengajarkan pimpinan Roh Kudus dalam membimbing murid yang lahir baru dalam menerima Tuhan Yesus Kristus. ${ }^{32}$

Pendidikan Agama yang Kristen harus lebih dikembangjan, guna menghasilkan karakter siswa dan integritas dalam penghayatan kepada Tuhan, juga dalam hal memanusiakan manusia. Penyelengaraan pendidikan Kristen haruslah memiliki komitmen dalam melaksanak tugasnya. Serangan filosofi sekuler dan perkembangan dunia digital akan membawa dampak negatif pada pendidikan Kristen yang konservatif mempercayai Allah dan otoritas Alkitab. Khoe Yao Tung mengatakan kurikulum Kristen harus dibangun dari filsafat pendidikan Kristen yaitu Alkitab sumber satu-satunya pengajaran Agama Kristen dan satu-satunya sumber otoritas, kewenangan, dan kuasa dalam pengajaran dan mengimplementasikan kurikulum dalam kehidupan nyata setiap hari. Ia memberi sinyal bahwa kurikulum PAK di sekolah-sekolah akan direduksi untuk pembelajaran religiositas yang menekankan pada symbol-simbol, pemahaman agama, serta menekankan toleransi beragama. ${ }^{33}$

Alkitab meyakinkan para pelaku pendidikan kristiani bahwa kurikulum kristiani tidak dapat digantikan dengan dalil "penyesuaian" dan "standarisasi" karena Allah yang menghendaki pendidikan itu didirikan dan dikelolah sesuai dengan tingkat kewaspadaan yang tinggi di antara para pelaku pendidikan seperti yang tertera dalam Kolose 2:8-10.

Beberapa faktor penting dalam menyeleksi kurikulum PAK di sekolah yaitu: (1) Isi kurikulum PAK harus sesuai dengan Alkitab. (2) Kurikulum harus sesuai dengan ajaran dan pengakuan gereja yang menggunakannya. (3) Kurikulum PAK harus memanfaatkan

30Khoe Yao Tung, Menuju Sekolah Kristen Impian Masa Kini (Yogyakarta: Andi, 2015), 2

31Tung, Menuju Sekolah Kristen Impian Masa Kini, 11

32Tung, Menuju Sekolah Kristen Impian Masa Kini, 11

${ }^{33}$ Khoe Yao Tung, Filsafat Pendidikan Kristen: Meletakkan Fondasi dan Filosofi Pendidikan Kristen di Tengah Tantangan Filsafat Dunia (Yogyakarta: Andi, 2013), ix 
ilmu pedagogi dan ilmu psikologi. (4) Kurikulum harus sesuai dengan kebutuhan gereja tertentu. ${ }^{34}$

\section{d. Pelaksana PAK konteks sekolah}

Pelaksana PAK di sekolah umumnya dikerjakan oleh Guru Agama Kristen. Walaupun dibeberapa sekolah, khususnya sekolah-sekolah negeri ada guru yang tidak berlatar belakang guru PAK, tetapi seyoginya mereka memahami tugas dan tanggung jawab sebagai guru PAK. Hamrighausen dan Enklaar menjelaskan bahwa guru adalah penafsir iman Kristen, guru juga adalah gembala, pedoman dan pemimpin, dan guru juga adalah seorang penginjil. ${ }^{35}$ Itulah sebabnya para guru PAK hendaknya mengetahui syarat dan kriteria menjadi seorang guru PAK yang professional namun tetap menjaga status sebagai hamba Tuhan. Guru PAK harus benar-benar mengalami lahir baru dan pertobatan sejati. Guru PAK juga harus memiliki keterpanggilan, jiwa melayani, hati (passion) mengajar, Guru PAK harus memiliki seperangkat pengetahuan dan keterampilan sebagai wujud pernah berstudi dan mengecap pendidikan secara formal dan non formal. Seorang guru PAK hendaknya juga memiliki jiwa berkorban waktu, tenaga, materi dan bahkan harga diri agar ia lebih banyak memenangkan jiwa bagi Kristus di kelas-kelas pembelajaranya.

\section{KESIMPULAN}

Dari pembahasan di atas, dapat dipahami bahwa prinsip dan pelaksanaan Pendidikan Agama Kristen tidak dapat dipisahkan dari tiga konteks utama, yakni kontek keluarga, gereja dan sekolah.

Dari konteks keluarga kita didorong untuk memahami pengertian keluarga Kristen, pentingnya keluarga Kristen, prinsip utama dalam keluarga Kristen, peran dalam keluarga Kristen, dan hirarki keluarga Kristen. Kontek gereja mengarahkan kita pada pengertian gereja, hikmat gereja, dan fungsi dan tujuan gereja. Dan konteks sekolah mencakup pengertian sekolah, sekolah sebagai tempat proses pembelajaran PAK, kurikulum PAK, dan pelaksana PAK konteks sekolah.

Ketiga konteks tersebut tidak dapat dipisahkan dari prinsip dan penerapan PAK. Para pelaku PAK terutama para pendidid seyogianya memperhatikan ketiga konteks tersebut dalam rangka mencapai efektifitas dan tujuan PAK yang telah ditetapkan.

34Tanya, Gereja dan Pendidikan Agama Kristen, 33

${ }^{35}$ Hamrighausen dan Enklaar, Pendidikan Agama Kristen, 164 


\section{Referensi}

Antone, Hope S., Pendidikan Kristiani Kontekstual. Jakarta:BPK.Gunung Mulia, 2010.

Cully, Iris V., Dinamika Pendidikan Kristen. Jakarta:BPK. Gunung Mulia, 1993.

Departemen Pendidikan dan Kebudayaan, Kamus Besar Bahasa Indonesia. (Jakarta: PT. Gramedia Pustaka Utama, 2014.

Edelin, Richard J. , Hakikat Pendidikan Kristen. Jakarta: BPK. Gunung Mulia, 2015.

Homrighausen, E.G.dan I.H. Enklaar, Pendidikan Agama Kristen. Jakarta: BPK. Gunung Mulia, 2008.

Kolibu, Dirk Roy, Teologi Pendidikan Agama Kristen. Jakarta: Pascasarjana UKI, 2020.

Nuhamara, Daniel, Pembimbing Pendidikan Agama Kristen . Bandung: Infomedia, 2007. -, Pendidikan Agama Kristen di Perguruan Tinggi. Bandung:Bina Media Informasi, 2007.

Parapak, Jonathan, Pembelajar dan Pelayan: Di sekitar iman, teknologi, pendidikan dan pelayanan gerejawi. Jakarta: Institut Dharma Mahardika, 2002.

Riemer, G., Ajarlah Mereka Melakukan. Jakarta: YKBK/OMF, 2006.

Rupp, Anne Neo Feld, Tumbuh Kembang Bersama Anak. Jakarta:BPK. Gunung Mulia, 2009.

Schipani, Daniel S., "Pendidikan Transformasi Sosial" dalam Memetakan Pendidikan Kristen: Pendekatan-pendekatan menuju Pembelajaran Jemaat. Jakarta: BPK. Gunung Mulia, 2016.

Sitompul, A. A., Mencerdaskan Anak Bangsa Menuju Millenium Baru. Jakarta: Kebangkitan Hidup Baru, 1999.

Stephanus, Daniel, Pendidikan Agama Kristen Kemajemukan. Bandung: Bina Media Indonesia, 2009.

Tanya, Ely , Gereja dan Pendidikan Agama Kristen. Cipanas: STTC, 2006.

Tong, Stephen, Keluarga Bahagia. Surabaya: Momentum, 2012.

Tung, Khoe Yao, Menuju Sekolah Kristen Impian Masa Kini. Yogyakarta: Andi, 2015.

----------, Filsafat Pendidikan Kristen: Meletakkan Fondasi dan Filosofi Pendidikan Kristen di Tengah Tantangan Filsafat Dunia. Yogyakarta: Andi, 2013.

Ward, Ted, Nilai Hidup dimulai dari Keluarga. Malang: Gandum Mas, 1976.

Wuwungan, O.E.CH., Pemahaman Alkitab dan Warga Gereja .Jakarta: Pustaka Sinar Harapan, 1997.

http://www.charismata.id/2017/05/pengertian-keluarga-kristen.html, diunduh hari Rabu tanggal 22 April 2020 pukul 17:00 WIB

https://WwW.seputarpengetahuan.co.id/2017/08/15-pengertian-keluarga-menurutpara-ahli.html, diunduh hari Rabu tanggal 22 April 2020 pukul 17:00 WIB 